\title{
SOIL-CORROSION STUDIES, 1927-28
}

\author{
By K. H. Logan
}

ABSTRACT

This paper is the second progress report on the soil-corrosion studies, supplementing Technologic Paper No. $368^{1}$ which set forth the plan of the investigation, described the soils and materials under test, and gave the data obtained up to and including 1926 . The present report supplements the earlier one, gives additional data on the chemical properties of the soils and materials, and records the results of the examination of specimens removed in 1928. These specimens include only ferrous pipe materials and cable sheaths, no specimeus of nonferrous materials other than cable sheaths, pipe coatings, or galvanized sheet being removed. The results of some laboratory and special field investigations are described. Soil characteristics, rather than differences in the composition of the ferrous pipe materials, appear to determine the type and extent of the corrosion observed. Tables show the relative corrosiveness of soils based on rate of loss of weight and rate of increase in depth of pits. Although it happened that the same soil was worst from both of these points of view, the soil that ranked next to the worst from the standpoint of pitting ranked twenty-eighth as to loss of weight.

As the specimens in the ground grew older the corrosion became more general, and in most soils there was a decrease in the rate of penetration. Field examination of cast-iron gas mains in several cities yielded data of a similar nature.

Preliminary studies indicated that, in addition to the highly localized galvanic action caused by mill scale, oxygen concentration cells, differences in soil contacts, etc., there are on long pipe lines galvanic currents that are the result of the line passing through different soils. There appeared to be a relation between the discharge of these galvanic currents and the corrosion observed on the pipe line.

Considerable work has been done recently on methods of predetermining the corrosiveness of soils. The problem has not been solved.

Additional specimens of pipe materials and coatings will probably be removed in 1930.

1 B. S. Tech. Papers, 22, pp. 447-554, 1929. 
I. Introduction

II. Additional data on soils

III. Results of analyses of ferrous pipe materials

IV. Trend of the results of field tests of pipe specimens

1. Rates of corrosion

2. Rates of pitting

(a) Method of determining rates_.............. 284

(b) Limitations of the data_...... 287

3. Pitting factors... 291

4. Comparison of soils_._. 291

(a) With respect to rates of corrosion _._._._._. 291

(b) With respect to rates of pitting _........... 293

(c) With respect to soil texture._._._._._._. 294

5. Comparison of materials___._. 295

6. Application of results to specific corrosion problems_...... 296

V. Results of supplementary research on pipe lines_._._._._. 296

1. Inspection of gas mains _... 296

2. Corrosion accompanied by galvanic action _.......... 297

VI. Results of tests of other materials used underground _._._. 300

1. Corrosion of high-silicon cast iron

2. Corrosion of lead cable sheath

3. Corrosion of parkway cable

VII. Summary _.

\section{INTRODUCTION}

In April, 1928, the Bureau of Standards issued its first Technologic Paper $^{2}$ on its soil-corrosion investigation. That paper outlined the purpose and scope of the work then under way and gave such data concerning the soils, materials, and results of the work as were then available. The present paper is intended to supplement the earlier report and bring the results up to date. The work now under way will not be completed before 1935, and until then it is expected that progress reports will be issued from time to time as results become available. With respect to time, the investigation is now half completed, although but a little over a third of the 15,000 buried specimens have been removed.

The data discussed in the first technologic paper on soil-corrosion were obtained prior to 1927 . Since that time considerable progress has been made. The Cast-Iron Pipe Research Association has employed an associate to assist in the study of soil corrosion, and the bureau has increased the number of men on this work. Assistance has also been secured from outside organizations, as will be noted in more detail later. As a result of this assistance, considerable progress has been made along several lines, but much remains to be done.

${ }^{2}$ B. S. Tech. Paper No. 368, Bureau of Standards Soil-Corrosion Studies. I. Soils, Materials, and Results of Early Observations. 
The first conference on bituminous protective coatings for pipes ${ }^{3}$ not only brought out the inadequacy of most of the coatings under test, but showed also the difficulty of determining the quality of a coating under consideration. It became apparent that a satisfactory study of protective coatings would involve extensive work in the laboratory to develop methods of testing coatings, as well as a large amount of field work to determine the character of coatings suitable for the varied conditions to which pipe lines are exposed. A little work has been done on the development of methods for testing protective coatings, and it is expected that this work will be continued during the coming year. Arrangements have been made for studies of protective coatings by research associates employed by the American Petroleum Institute and the American Gas Association.

\section{TABLE 1.-Results of soil analyses}

[In per cent of weight of dry soil]

\begin{tabular}{|c|c|c|c|c|c|c|c|c|}
\hline No. & Description & $\begin{array}{l}\text { Loss } \\
\text { by ig- } \\
\text { nition }\end{array}$ & S & $\begin{array}{l}\text { Insol- } \\
\text { uble }\end{array}$ & $\mid \begin{array}{c}\mathrm{Fe}_{2} \mathrm{O}_{3}-1-1 \\
\mathrm{Al}_{2} \mathrm{O}_{3}\end{array}$ & $\mathrm{CaO}$ & $\mathrm{MgO}$ & $\mathrm{pH}$ \\
\hline $\begin{array}{l}1 \\
2 \\
3 \\
4 \\
5\end{array}$ & $\begin{array}{l}\text { Allis silt loam } \\
\text { Bell clay } \\
\text { Cecil clay loam } \\
\text { Chester loam } \\
\text { Dublin clay adobe... }\end{array}$ & \begin{tabular}{|c} 
Per cent \\
7.06 \\
10.40 \\
12.00 \\
4.44 \\
7.14
\end{tabular} & $\begin{array}{c}\text { Per cent } \\
0.08 \\
.05 \\
.04 \\
.03 \\
.01\end{array}$ & $\begin{array}{c}\text { Per cent } \\
83.8 \\
82.6 \\
60.46 \\
79.5 \\
85.5\end{array}$ & $\begin{array}{c}\text { Per cent } \\
8.4 \\
4.6 \\
23.6 \\
14.4 \\
5.7\end{array}$ & $\begin{array}{c}\text { Per cent } \\
0.32 \\
.54 \\
.30 \\
.30 \\
.24\end{array}$ & $\begin{array}{c}\text { Pcr cent } \\
0.09 \\
.32 \\
.40 \\
.69 \\
.50\end{array}$ & $\begin{array}{r}\text { Per cent } \\
7.0 \\
7.4 \\
7.2 \\
7.8\end{array}$ \\
\hline $\begin{array}{r}6 \\
7 \\
8 \\
9 \\
12\end{array}$ & $\begin{array}{l}\text { Everett gravelly sand } \\
\text { Fairmount silt loam } \\
\text { Fargo clay loam } \\
\text { Genesee silt loam } \\
\text { Hanford fine sandy }\end{array}$ & $\begin{array}{r}3.40 \\
11.72 \\
15.70 \\
7.26 \\
3.48\end{array}$ & $\begin{array}{l}.03 \\
.04 \\
.11 \\
.03 \\
.04\end{array}$ & $\begin{array}{l}87.6 \\
83.5 \\
64.2 \\
88.4 \\
87.8\end{array}$ & $\begin{array}{l}7.1 \\
4.1 \\
8.4 \\
3.1 \\
5.9\end{array}$ & $\begin{array}{r}.40 \\
.30 \\
6.80 \\
.30 \\
.40\end{array}$ & $\begin{array}{r}.58 \\
.29 \\
2.68 \\
.40 \\
.94\end{array}$ & $\begin{array}{l}6 . \\
7 . \\
8 \\
8 \\
7 .\end{array}$ \\
\hline $\begin{array}{l}13 \\
14 \\
15 \\
16 \\
18\end{array}$ & $\begin{array}{l}\text { Hanford very fine sandy loam } \\
\text { Hempstead silt loam } \\
\text { Houston biack clay } \\
\text { Kalmia fine sandy loam } \\
\text { Knox silt loam }\end{array}$ & $\begin{array}{r}4.74 \\
2.74 \\
15.00 \\
3.60 \\
4.60\end{array}$ & $\begin{array}{l}.03 \\
.05 \\
.08 \\
.11 \\
.07\end{array}$ & $\begin{array}{l}83.5 \\
89.8 \\
74.0 \\
20.4 \\
86.4\end{array}$ & \begin{tabular}{l|}
8.0 \\
4.46 \\
5.40 \\
3.20 \\
6.5
\end{tabular} & $\begin{array}{r}1.10 \\
1.53 \\
3.58 \\
.34 \\
.30\end{array}$ & $\begin{array}{r}1.16 \\
.83 \\
1.00 \\
.33 \\
.50\end{array}$ & $\begin{array}{l}7.6 \\
8.4 \\
7.0 \\
8.6\end{array}$ \\
\hline $\begin{array}{l}19 \\
20 \\
21 \\
22 \\
25\end{array}$ & $\begin{array}{l}\text { Lindley silt loam } \\
\text { Mahoning silt loam.- } \\
\text { Marshall silt loam } \\
\text { Memphis silt loam.- } \\
\text { Miami clay loam.-. }\end{array}$ & $\begin{array}{r}5.80 \\
6.00 \\
6.60 \\
5.00 \\
20.40\end{array}$ & $\begin{array}{l}.07 \\
.06 \\
.15 \\
.06 \\
.08\end{array}$ & $\begin{array}{l}84.3 \\
81.6 \\
89.2 \\
85.0 \\
49.3\end{array}$ & $\begin{array}{r}\text { 7. } 9 \\
10.80 \\
3.20 \\
4.80 \\
14.80\end{array}$ & $\begin{array}{r}.30 \\
.30 \\
.30 \\
.30 \\
11.80\end{array}$ & $\begin{array}{r}.80 \\
.72 \\
.43 \\
.47 \\
2.82\end{array}$ & $\begin{array}{r}6.9 \\
-7.2 \\
6.8 \\
8.0\end{array}$ \\
\hline $\begin{array}{l}26 \\
27 \\
28 \\
29 \\
30\end{array}$ & $\begin{array}{l}\text { Miami silt loam } \\
\text { Miller clay. } \\
\text { Montezuma clay adobe } \\
\text { Muck } \\
\text { Muscatine silt loam }\end{array}$ & $\begin{array}{r}19.34 \\
12.98 \\
3.60 \\
28.40 \\
6.80\end{array}$ & $\begin{array}{l}.09 \\
.08 \\
.08 \\
.24 \\
.03\end{array}$ & $\begin{array}{l}51.24 \\
81.40 \\
93.0 \\
62.0 \\
82.4\end{array}$ & $\begin{array}{r}17.30 \\
2.00 \\
2.80 \\
7.50 \\
7.90\end{array}$ & $\begin{array}{r}10.86 \\
1.80 \\
.20 \\
.80 \\
.80\end{array}$ & $\begin{array}{l}1.52 \\
1.30 \\
.29 \\
.69 \\
.76\end{array}$ & $\begin{array}{l}8.2 \\
8.4 \\
7.4 \\
7.0 \\
7.6\end{array}$ \\
\hline $\begin{array}{l}31 \\
32 \\
33 \\
34 \\
35\end{array}$ & $\begin{array}{l}\text { Norfolk sand } \\
\text { Ontario loam } \\
\text { Peat } \\
\text { Penn silt loam } \\
\text { Ramona loam }\end{array}$ & $\begin{array}{r}.76 \\
4.60 \\
63.22 \\
4.40 \\
6.30\end{array}$ & $\begin{array}{l}.03 \\
.06 \\
.04 \\
.03 \\
.03\end{array}$ & $\begin{array}{l}98.6 \\
85.3 \\
22.1 \\
84.8 \\
90.1\end{array}$ & $\begin{array}{l}1.00 \\
6.40 \\
4.40 \\
9.10 \\
2.46\end{array}$ & $\begin{array}{r}.20 \\
2.00 \\
6.80 \\
.40 \\
.78\end{array}$ & $\begin{array}{r}.14 \\
1.21 \\
2.30 \\
.62 \\
.80\end{array}$ & $\begin{array}{l}6.9 \\
8.4 \\
8.6 \\
7.4 \\
8.0\end{array}$ \\
\hline $\begin{array}{l}36 \\
37 \\
38 \\
39\end{array}$ & $\begin{array}{l}\text { Ruston sandy loam } \\
\text { St. Johns fine sand. } \\
\text { Sassafras graveily sandy loam } \\
\text { Sassafras silt loam. }\end{array}$ & $\begin{array}{r}4.86 \\
4.54 \\
.20 \\
7.00\end{array}$ & $\begin{array}{l}.04 \\
.03 \\
.05 \\
.04\end{array}$ & $\begin{array}{l}81.9 \\
93.0 \\
96.7 \\
92.8\end{array}$ & $\begin{array}{r}10.20 \\
2.00 \\
3.20 \\
1.70\end{array}$ & $\begin{array}{l}.40 \\
.30 \\
.10 \\
.30\end{array}$ & $\begin{array}{l}.40 \\
.10 \\
.12 \\
.40\end{array}$ & $\begin{array}{l}7.0 \\
6.9 \\
7.0 \\
7.0\end{array}$ \\
\hline $\begin{array}{l}40 \\
41 \\
42 \\
43\end{array}$ & $\begin{array}{l}\text { Sharkey clay } \\
\text { Summit silt loam } \\
\text { Susquehanna clay. } \\
\text { Tidal marsh }\end{array}$ & $\begin{array}{r}7.90 \\
8.56 \\
7.60 \\
15.80\end{array}$ & $\begin{array}{r}.06 \\
.21 \\
.34 \\
2.21\end{array}$ & \begin{tabular}{l|}
83.6 \\
84.62 \\
79.90 \\
71.22
\end{tabular} & $\begin{array}{r}6.70 \\
4.68 \\
10.70 \\
9.46\end{array}$ & $\begin{array}{l}.40 \\
.30 \\
.34 \\
.56\end{array}$ & $\begin{array}{r}.59 \\
.65 \\
.56 \\
1.07\end{array}$ & $\begin{array}{l}8.0 \\
7.4\end{array}$ \\
\hline $\begin{array}{l}44 \\
45 \\
46 \\
47\end{array}$ & $\begin{array}{l}\text { Wabash silt loam } \\
\text { Alkali soil } \\
\text { Sandy loam } \\
\text { Silt loam }\end{array}$ & $\begin{array}{r}8.20 \\
6.80 \\
.64 \\
21.52\end{array}$ & $\begin{array}{r}.42 \\
1.00 \\
.18 \\
.24\end{array}$ & $\begin{array}{l}87.58 \\
86.00 \\
95.22 \\
41.70\end{array}$ & $\begin{array}{l}2.40 \\
1.20 \\
1.40 \\
9.16\end{array}$ & $\begin{array}{r}.34 \\
2.54 \\
22.30 \\
22.00\end{array}$ & $\begin{array}{r}.70 \\
.33 \\
.00 \\
2.27\end{array}$ & $\begin{array}{l}8.4 \\
8.6 \\
8.6\end{array}$ \\
\hline
\end{tabular}

Note.-Leaders in figure columns indicate that determination was impossible. Slight inaccuracies in some of the water analyses are due to the extremely small amount of solution available for some determinations.

${ }^{3}$ See B. S. Tech. Paper No. 368, p. 521. 
TABLE 2.-Results of analyses of solution

[By parts per million of soil]

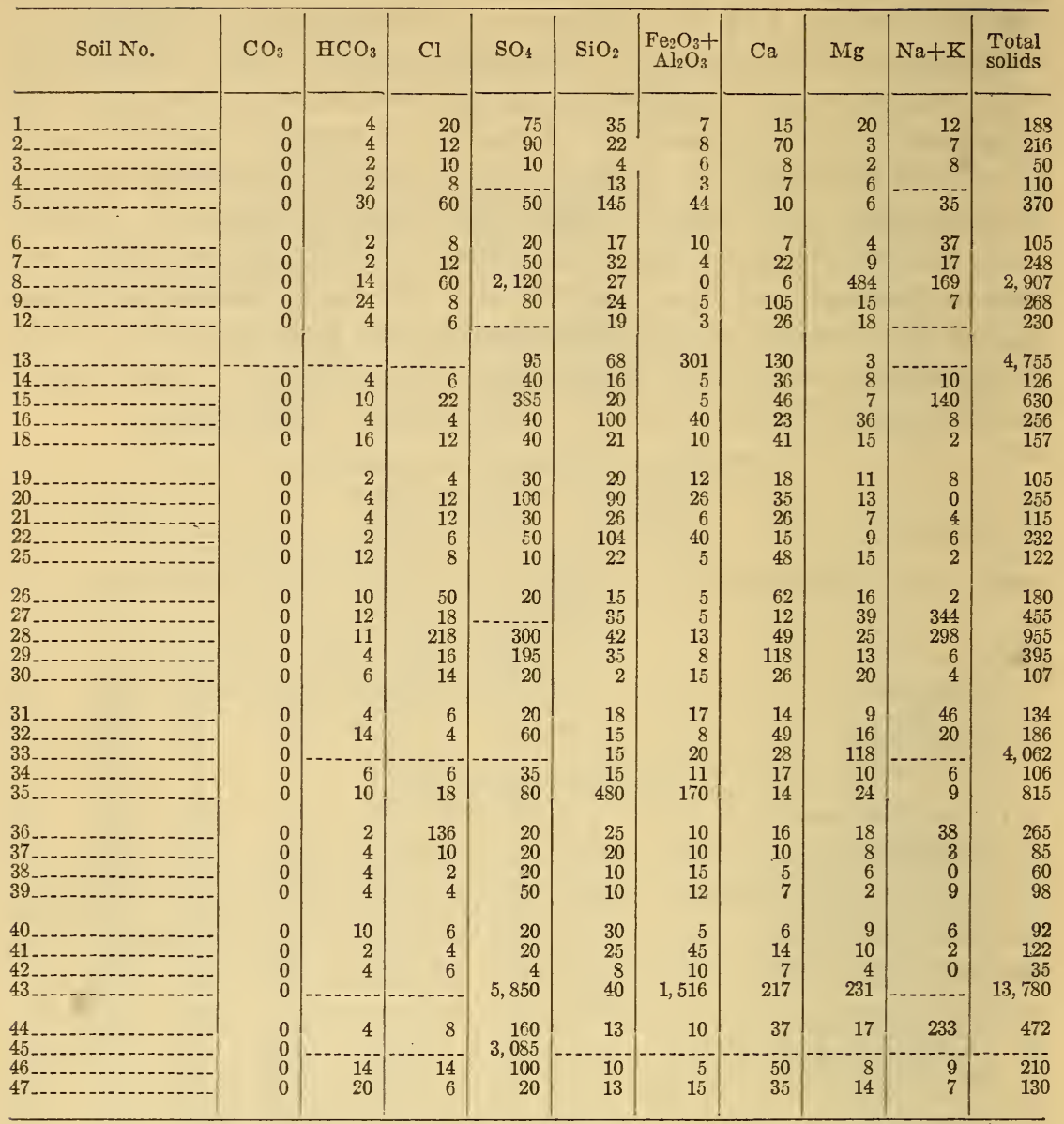

Note.-Leaders in figure columns indicate that determination was impossible. Slight inaccuracies in some of the water analyses are due to the extremely small amount of solution available for some determinations.

\section{ADDITIONAL DATA ON SOILS}

There is a belief on the part of many that soil corrosion is closely related to the chemical nature of the soil. We were fortunate, therefore, in securing the cooperation of J. W. Richards \& Son, industrial chemists, who have made the analyses shown in Tables 1 and 2 of the soils in which specimens have been buried. Their method of preparing the water cxtract in which the salt content of the soil was determined, as described by Percy J. Richards, was as follows: "Six ounces of the soil sample are mixed with $300 \mathrm{cc}$ of boiled distilled water in a small bottle; the contents should be thoroughly 
agitated at least 10 times a day for six days **** then filter into a clean bottle and cork for analysis."

When the rates of corrosion of the specimens have been more definitely established by the examination of more specimens, these tables may be very helpful in the study of the relation of the chemical nature of the soil to corrosion. At the present time, such a relation is not well established. It is not to be expected that a knowledge of the constituents of the soil will in itself make possible a prediction as to the rate of corrosion, since the supply of oxygen and water may be factors. The amounts of oxygen and water reaching the specimens depend upon the position of the trench in which specimens are buried, the type of soil, and the amount and distribution of rainfall.. The soil descriptions given in Technologic Paper No. 368 include the soil characteristics and drainage, while the rainfall and temperature can be judged in a general way by the location of the specimens, or more detailed data can be secured from the reports of the Weather Bureau. It has been suggested that weather conditions for the months immediately preceding and following the burial of the specimens may have affected the type of initial corrosion product formed and, consequently, the subsequent rate of corrosion. $\mathrm{Pl}$ ans for a study of this question are under way.

The amount of colloidal matter in a soil may have a bearing on corrosion because of the relation of colloids to the ability of the soil to absorb and hold water and because of the change in volume of soils containing large amounts of colloids with change in moisture content. Information on the colloid content, as determined by the method of Bouyoucos, ${ }^{4}$ is given in Table 3 .

TABLE 3.-Soil colloids ${ }^{a}$

\begin{tabular}{|c|c|c|c|c|c|c|c|}
\hline Soil No. & Per cent & Soil No. & Per cent & Soil No. & Per cent & Soil No. & Per cant \\
\hline $\begin{array}{l}1 \ldots \\
2 \ldots-. .- \\
3 .-.- \\
4 . . .-\end{array}$ & $\begin{array}{l}63.6 \\
46.6 \\
43.3 \\
25.3\end{array}$ & $\begin{array}{l}13 \\
14 \\
15 \\
16\end{array}$ & $\begin{array}{l}17.8 \\
32.0 \\
63.1 \\
20.8\end{array}$ & $\begin{array}{l}25 \ldots \\
26 \\
27 \\
28 \\
2\end{array}$ & $\begin{array}{l}31.0 \\
50.1 \\
91.4 \\
29.1\end{array}$ & $\begin{array}{l}37 \ldots \\
33 \ldots \ldots \\
39 \\
40\end{array}$ & $\begin{array}{r}6.6 \\
5.5 \\
15.5 \\
49.8\end{array}$ \\
\hline $\begin{array}{l}5 \ldots \\
6 \ldots \\
7 \\
8 \\
-\ldots . .-\end{array}$ & $\begin{array}{l}44.8 \\
11.1 \\
70.3 \\
66.0\end{array}$ & $\begin{array}{l}17 \ldots \\
18 \ldots \\
19 \ldots \\
20 \ldots\end{array}$ & $\begin{array}{l}76.0 \\
28.8 \\
38.9 \\
43.6\end{array}$ & $\begin{array}{l}29 \\
30 \\
31 \\
32\end{array}$ & $\begin{array}{r}24.5 \\
41.6 \\
1.1 \\
22.7\end{array}$ & $\begin{array}{l}41 \\
42 \\
44\end{array}$ & $\begin{array}{l}44.0 \\
44.6 \\
51.0 \\
31.5\end{array}$ \\
\hline $\begin{array}{l}9 \\
10 \\
11\end{array}$ & $\begin{array}{r}35.9 \\
15.9 \\
52.5 \\
8.9\end{array}$ & $\begin{array}{l}21 \\
22 \\
23 \\
24\end{array}$ & $\begin{array}{r}42.8 \\
33.2 \\
17.9 \\
7.2\end{array}$ & $\begin{array}{l}33 \\
34 \\
35 \\
30\end{array}$ & $\begin{array}{l}20.4 \\
41.9 \\
20.0 \\
37.9\end{array}$ & $\begin{array}{l}45 \\
46 \\
47\end{array}$ & $\begin{array}{r}7.0 \\
53.6\end{array}$ \\
\hline
\end{tabular}

a Determinations by Dr. S. P. Ewing, Bureau of Standards.

4 The Hydrometer as a New and Rapid Method for Determining the Colloidal Content of Soils, B. J. Bouyoucos, Soil Science, 23, No. 4, p. 319. 


\section{RESULTS OF ANALYSES OF FERROUS PIPE MATERIALS}

Earlier reports have stated that the several kinds of ferrous pipe materials in any one soil showed similar corrosion patterns and that for any one material this pattern varied with the soil. The indications were, therefore, that the initial corrosion was determined largely by soil characteristics.

There were, however, minor differences, which appeared to be caused by differences in the pipe materials, and these may become more pronounced on the specimens which are exposed longer. For this reason the character of the material under test is of interest. Since the specimens were selected from stock, not all of the specimens of any one material were necessarily produced at the same time, and, consequently, they may differ somewhat in composition. An attempt has been made to gain some idea of the character of the materials by analysis of a few specimens. Most of these analyses were furnished by the manufacturer at the time he furnished specimens. In a few places, as indicated in Table 4 , the analyses were made by the A. O. Smith Corporation, who analyzed the other rolled specimens also.

TABLE 4.-Results of chemical analyses of pipe materials in the Bureau of Standards soil-corrosion investigation

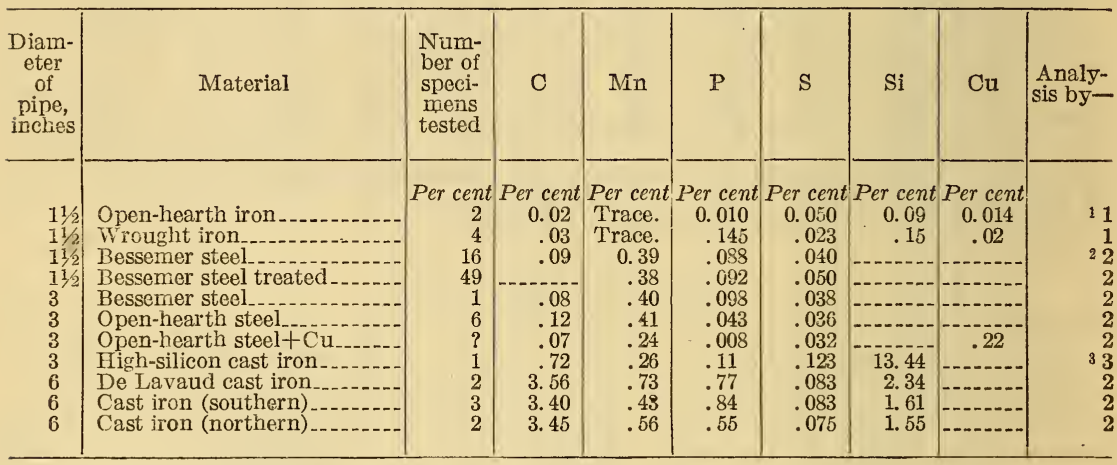

1 A. O. Smith Corporation.

2 Manúfacturer furnishing material.

3 United States Cast-Iron Pipe \& Foundry Co.

\section{TREND OF THE RESULTS OF FIELD TESTS OF PIPE SPECIMENS}

The soil-corrosion specimens removed in 1928 were limited to specimens of pipe and cable sheath buried in 1922. The specimens have been cleaned and the depth of pits measureed. Data on each individual specimen can be supplied to those needing these details, but for most purposes the average results presented in Tables 5, 6, and 7 are sufficient.

Space limitations make it impracticable to include the names of the soils in these tables. The names and locations of the soils cor- 
responding to the soil numbers in Tables 5, 6, and 7 will be found in Table 8. It should be understood that the soil under test in or near a given city is not necessarily characteristic of the soil of that city; for example, there is little Cecil clay loam to be found in the built-up section of the city of Atlanta, Ga., and there is very little Susquehanna clay within the city limits of Meridian, Miss.

Since the preparation of the progress reports presented at the meetings of the American Foundrymen's Association in 1925 and 1927, several soils have been reidentified, and this has resulted in a rearrangement of the alphabetical list of soils. As these progress reports had rather wide circulation, it appears desirable to indicate the change in soil numbers, and this is done in Table 9.

Comparison of the rates of corrosion and pitting for the 2, 4, and 6 year periods are of interest. In comparing results in different soils it must be kept in mind that the periods of burial, especially the first periods, are somewhat different in different parts of the country. In most cases, the rates of corrosion and pitting are greatest for the first period.

\section{RATES OF CORROSION}

Since specimens of De Lavaud cast iron were not buried in all of the test locations until some time after the other specimens were buried, they were not removed in 1928 from some of the soils. Moreover, the data on loss of weight of the first specimens buried were based on corrosion on both the inside and the outside surfaces of the pipe, as was the case with all other specimens. While the two surfaces of the other specimens were substantially the same, the outer surface of De Lavaud cast iron differs materially from the inside surface, as was evidenced from the appearance of the surfaces after corrosion. For these reasons we have not included the data on De Lavaud cast iron in summarizing the data.

If we take the data on four or more of the six classes of material in Table 5 in any one soil (De Lavaud cast iron being disregarded) as indicative of the trend of the corrosion in that soil, we find that in 17 out of the 45 soils from which specimens were removed in 1928 there has been a decrease in the rate of corrosion throughout the period of the investigation. In 5 other soils the rate for the 1928 specimens was less than that for the specimens removed in 1926, and in 10 other soils the rate for the third period was less than that for the first period. In only 2 soils was there a progressive increase in the rate of corrosion. In 11 soils the rate for 1928 was greater than for 1926. In a considerable number of cases the variations in the apparent rates seemed due to accidental occurrences incident to conditions at time of burial. If we average the results in all soils, we find that for each material there was a continuous decrease in the rate of corrosion. 


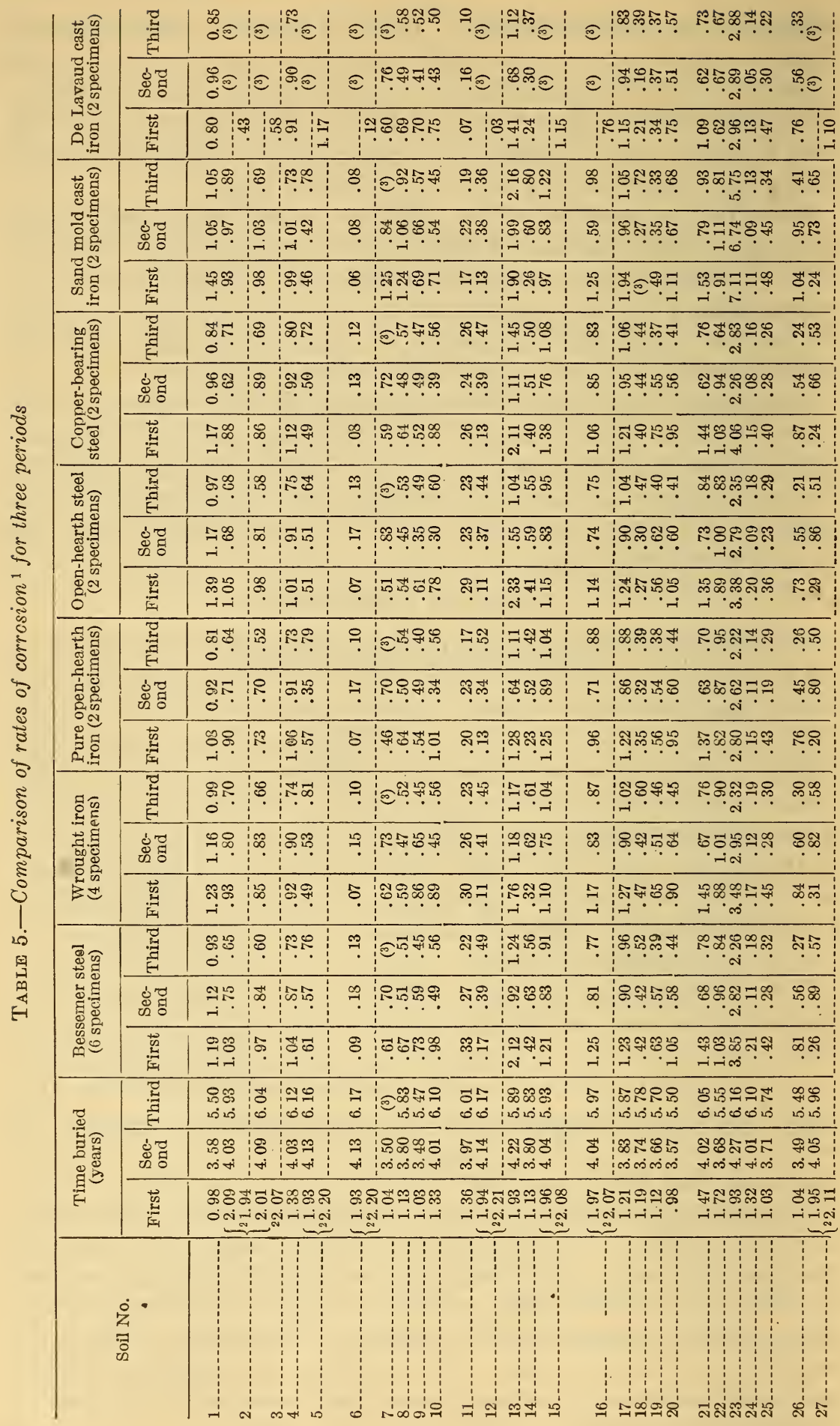




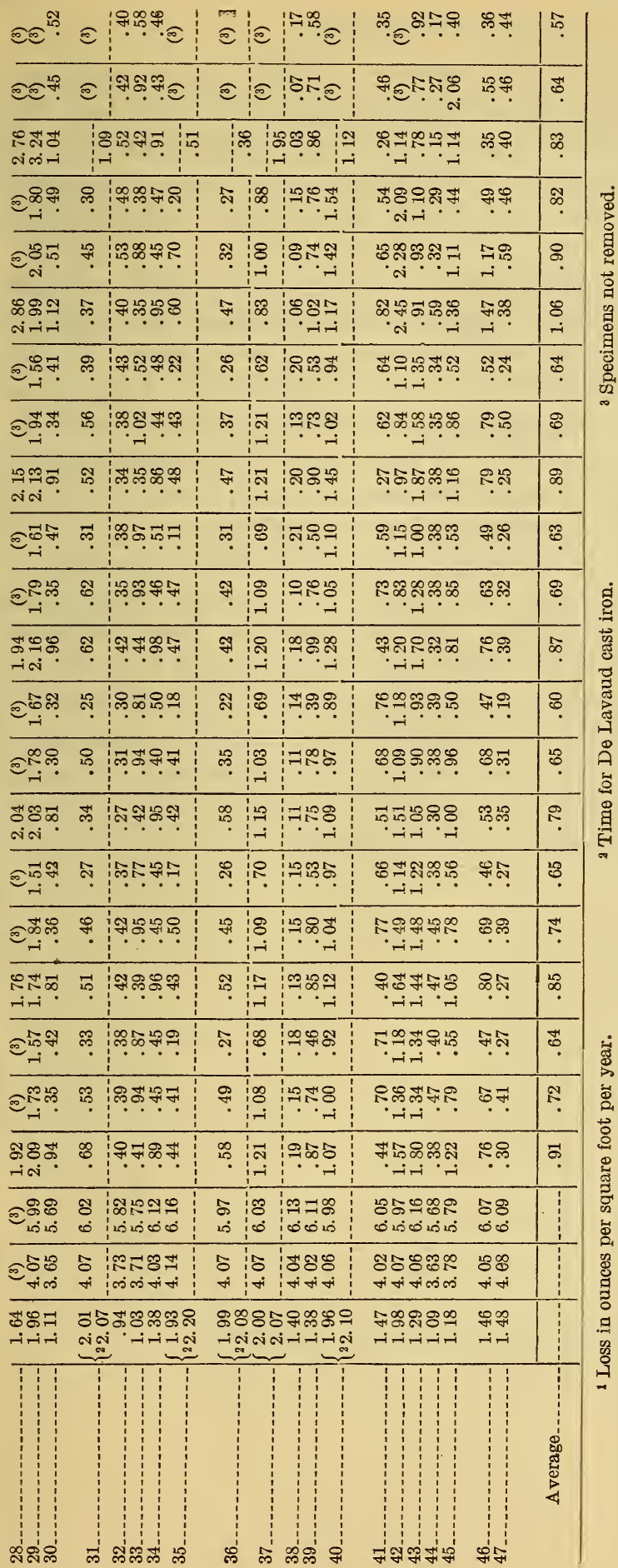




\section{RATES OF PITTING}

(a) Method of Determining Rates.-Table 6 shows the averages of the maximum rates of pitting for each class of material. The depth of the deepest pit on each specimen was first divided by the period the specimen was buried, then the average was obtained by dividing the sum of these quotients by the number of specimens in the class.

As the smoothness of specimens of commercial pipe was not sufficient to permit the accurate measurement of shallow pits, the rule was adopted that no record should be made of pits less than 0.02 inch in depth. When no specimen in a class of material in a given soil was pitted sufficiently to justify measurement, no pitting rate was given for this class in that soil. If only part of the specimens in a class were pitted deeply enough for measurement, it was necessary to make some assumption regarding the pitting of the other specimens if an average was to be obtained. It was decided, therefore, to assume that the total depth of the deepest pit on each unmeasured specimen was 0.02 . While the resultant rates for these specimens were obviously somewhat too high, it was believed that they did not cause a serious error in the results, and for the sake of uniformity in method and comparability of results it was suggested that others who have occasion to compute average pitting data make the same assumptions. The depth of the pits was measured from a portion of the original surface preserved for this purpose. 


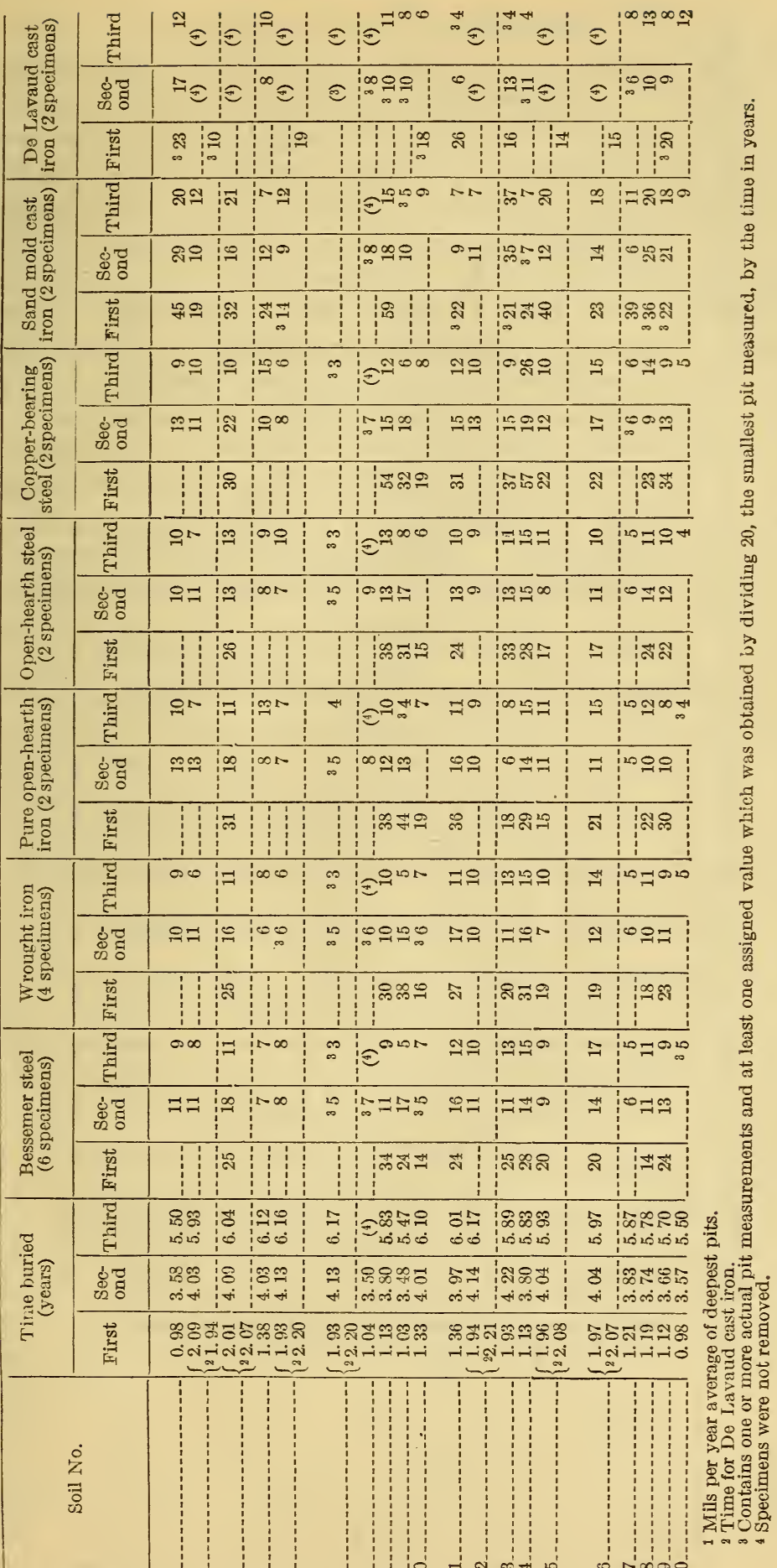


है

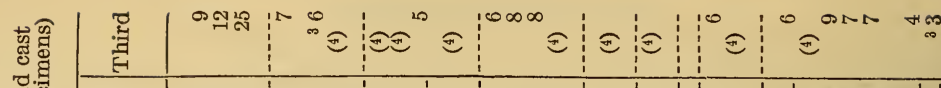

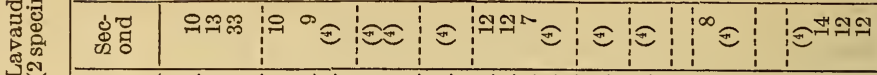

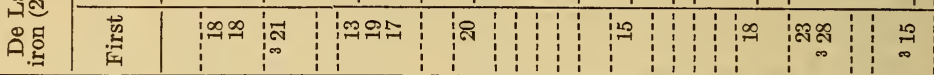

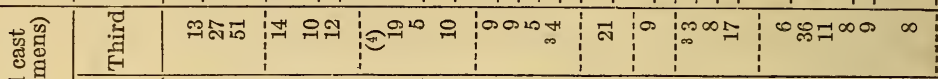

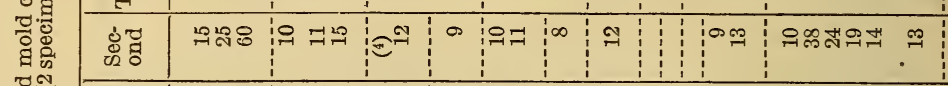

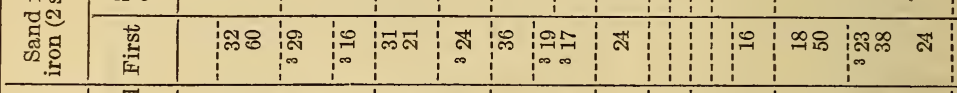

\begin{tabular}{|c|c|c|c|c|c|c|c|c|c|c|}
\hline \multirow{3}{*}{ 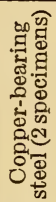 } & 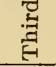 & \multicolumn{2}{|c|}{ बテनন } & \multicolumn{3}{|c|}{ 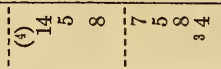 } & \multicolumn{2}{|c|}{$\therefore$} & $=120 \infty \mathbb{H}$ & $\infty \mathfrak{A} \infty)^{\infty}$ \\
\hline & 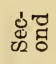 & ఈ్ㅀ్ & os 박요 & ๔ర్ల & $\infty$ & 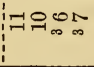 & 억 & !ø & 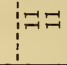 & $\infty \infty$ \\
\hline & $\begin{array}{l}\overrightarrow{0} \\
\text { 密 }\end{array}$ & |ลิ & : & & సิ & : & 옥 & : & : & 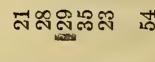 \\
\hline
\end{tabular}

\begin{tabular}{|c|c|c|c|c|c|c|c|c|c|c|}
\hline \multirow{3}{*}{ 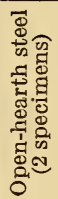 } & 㣢 & \multicolumn{4}{|c|}{ 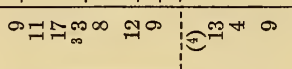 } & \begin{tabular}{|l|l|}
000 \\
\end{tabular} & 0 & \multicolumn{2}{|c|}{$\infty \operatorname{lin}_{\infty} 0 \mathbb{H}$} & 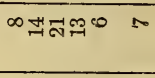 \\
\hline & 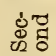 & बण्ग & : & 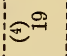 & $=$ & 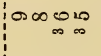 & $\cong$ & : & $\exists$ & 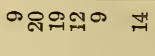 \\
\hline & 志 & โสุม & i & 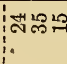 & $\mathscr{n}$ & โุ & $\ddot{N}$ & : & !ః & 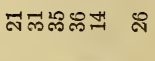 \\
\hline
\end{tabular}

\begin{tabular}{|c|c|c|c|c|c|c|c|c|c|}
\hline \multirow{3}{*}{ 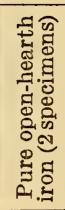 } & 营 & ๆางสล & $\widehat{C}^{\curvearrowright-\infty}$ & $H$ & Oon & $\begin{array}{l:l}\infty \infty & \end{array}$ & $\infty$ & 요 & 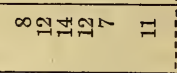 \\
\hline & 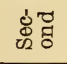 & ๑ง & : & $\therefore$ & : & $\infty$ & $\Rightarrow$ & & $\infty_{120}^{\circ}$ तू \\
\hline & 蒂 & \begin{tabular}{|l|l} 
: \\
:
\end{tabular} & & هـ & ঋ & 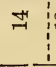 & $\infty$ & & 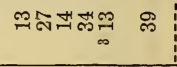 \\
\hline \multirow{3}{*}{ 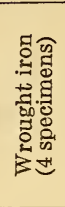 } & 荱 & 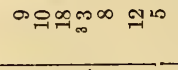 & & H & & N & in & & 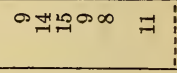 \\
\hline & 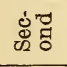 & 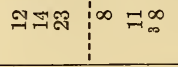 & $\forall$ & $\begin{array}{c:c}\infty & \\
\infty & \end{array}$ & $=\begin{array}{lll}-\infty & \infty & 0 \\
-\infty & \infty\end{array}$ & 0 & $\approx$ & $\Rightarrow$ & 유: \\
\hline & 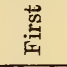 & :ส: & & 두 & : & 요 & I & 我 & 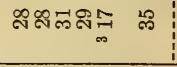 \\
\hline \multirow{3}{*}{ 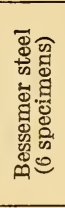 } & 苟 & 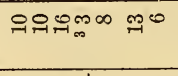 & & 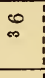 & $\int_{\infty}$ & $N$ & \multicolumn{2}{|r|}{$\Rightarrow$} & 유패벼유 에 \\
\hline & 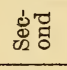 & ஐザさ & $\widehat{O}^{\infty-9}$ & N & thos & $\infty$ & $\because$ & $\infty$ & 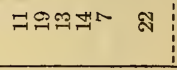 \\
\hline & 蒂 & 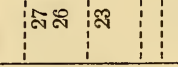 & 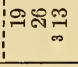 & $\stackrel{2}{2}$ & : & क & ผุ & 今 & 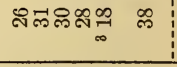 \\
\hline \multirow{3}{*}{ 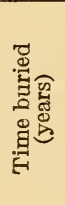 } & 学 & 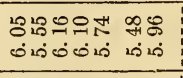 & 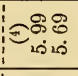 & o & 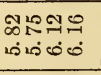 & 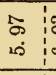 & $\begin{array}{l}8 \\
0 \\
0\end{array}$ & $\begin{array}{l}m=\infty \\
0=10 \\
000\end{array}$ & 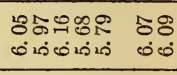 \\
\hline & 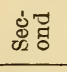 & 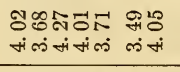 & $\begin{array}{l}\text { जion } \\
\text { tion }\end{array}$ & $\begin{array}{l}\text { s. } \\
\text { +i }\end{array}$ & 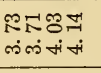 & $\begin{array}{l:ll}5 & 1 \\
+4 & 1 \\
\end{array}$ & مै & 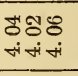 & 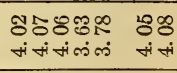 \\
\hline & 蒡 & 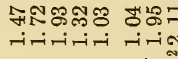 & & бం & & $8 \infty 8$ & & & 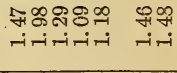 \\
\hline
\end{tabular}


Table 6 shows data in a few places where the corresponding Table 3 in Technologic Paper No. 368 gives none because in the latter table no figure was recorded if any of the specimens of a class showed no measurable pits. The plan followed in the technologic paper is preferable in that it involves no arbitrary assumptions but it suppresses some data and, if rigidly adhered to, makes it impossible to compute average results for either a soil or a pipe material.

(b) Limitations of the Data.-As is indicated at the top of Table 6, the data for some classes of material were obtained from more specimens than were available for some other classes. For example, there were two 11/2-inch specimens of Bessemer steel from each of two mills and two 3-inch specimens from a third mill. The outer surface of these specimens upon which pitting data could be obtained amounted to approximately 229 square inches. Only two $1 \frac{1}{2}$-inch specimens represented the open-hearth iron, and the exposed area amounted to about 60 square inches. Obviously, the chances for an unusually deep pit caused by abnormal conditions in material or soil were greater for the class of material having the greater exposed area, and the effect of a single deep pit was least when the group has a maximum number of specimens. If each of two groups contains the same number of specimens, the group made up of the larger specimens was at a disadvantage. For example, the cast-iron group, consisting of two 6-inch specimens, exposed about four times the area exposed by the two $1 \frac{1}{2}$-inch open-hearth iron specimens. The disadvantage of the larger specimens decreases as the pitting becomes more general, and for most soils it is not very important. Fortunately, we had one material furnished by two manufacturers, each of whom supplied specimens of two sizes. Each manufacturer recognized data on the other's product as representative of his own also. For the first and second periods the average rates of penetration on the $1 \frac{1}{2}$-inch specimens of each of these manufacturers was greater than on the corresponding 3 -inch specimens by not more than 1 mil per year, while the difference for the third period was 0.6 mil per year in favor of the larger specimens of one maker and zero for the other group. The differences were too small to be of importance. While the average results for all soils was unaffected by the size of the specimen because the total area of the smaller specimens was sufficient to be representative, the same thing may not hold true if materials in one soil are compared, because in the latter case the number of specimens is very limited.

These weaknesses in the pitting data now available are pointed out as one of the reasons why a decision as to the relative merits of materials should be deferred until data on more specimens are available. Later data will also be more accurate because there will be fewer cases in which the depth of the deepest pit will have to be 
assumed rather than measured and the conditions to which the specimens have been exposed will be more nearly representative of the average conditions encountered by a pipe line in the course of its life.

Examining Table 6, we find that in 26 soils at least two-thirds of the materials showed a continuous decrease in the rate of pitting while five other soils showed a lower rate in 1928 than in 1926, although the latter rate was greater than in 1924 .

It is noticeable that for most of the specimens both the rate of corrosion and the rate of pitting for the 6-year period was nearly the same as for the 4-year period. This indicates that the specimens have reached an approximately stable condition and that in the future the effects of the initial conditions of the test, such as the condition of the pipe surface, the stability of recently disturbed soil, etc., will be of minor importance. It is to be expected, therefore, that future data may be expected to be more nearly representative of the deterioration of pipe lines which have been in the ground a number of years. 


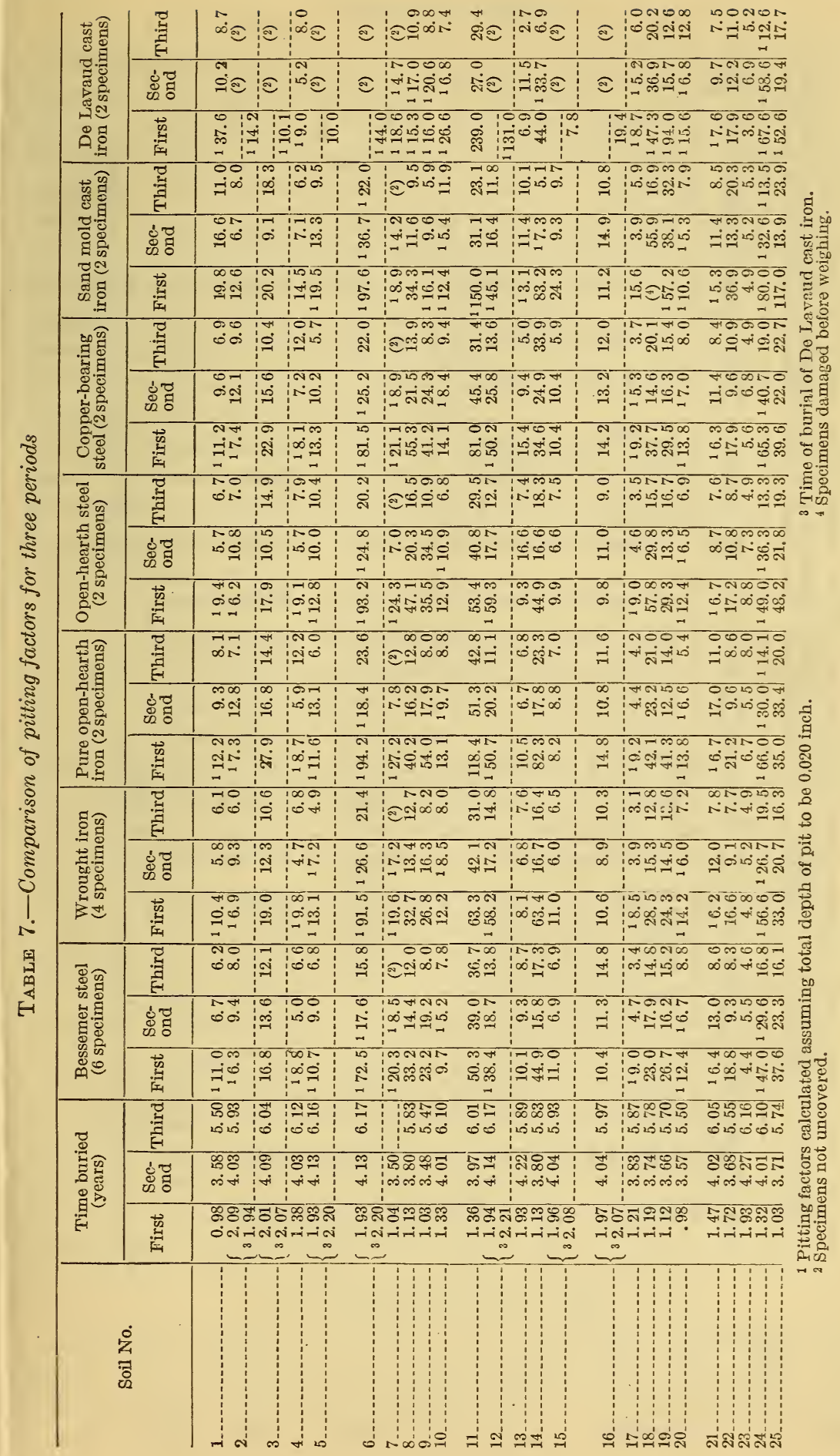




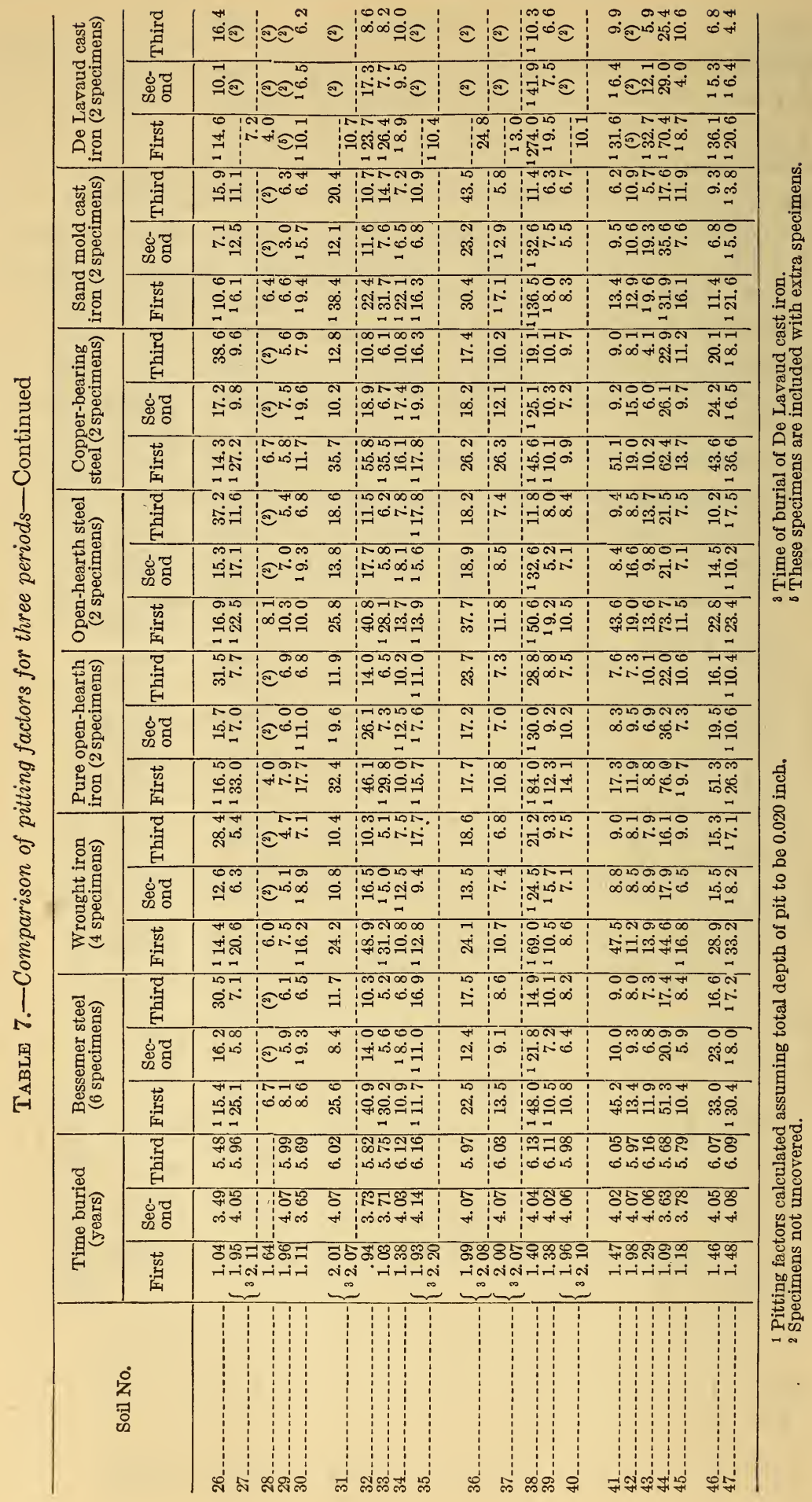




\section{PITTING FACTORS}

The pitting factor may be defined as the ratio of the depth of the deepest pit to the average depth of corrosion. The latter figure is obtained from the loss of weight, area, and density of the material. The pitting factor is not a measure of the seriousness of corrosion but indicates in a general way the nearness to uniformity of the corrosion. Table 7 shows the average pitting factors for the specimens at the end of three periods. In computing Table 7 the original data on total loss of weight and depth of pits have been used in preference to the average rates of loss and pitting shown in Tables 5 and 6 . This somewhat increases the accuracy of the data and explains why, in some cases, the data in Table 7 do not check exactly with results computed from the preceding tables.

It will be noted that, in general, the pitting factor decreased with time. This is one way of indicating that as the specimens grew older the rate of penetration decreased faster than the rate of loss of weight; that is, the corrosion became more generally distributed over the surface of the specimens.

It will be found that, on the average, the pitting factor was smaller for the older and more corroded specimens and that the factors for the 1926 and 1928 specimens were nearly alike and much smaller than for the specimens removed in 1924. The fact has an important bearing on the theory of corrosion. A number of authors have suggested that the presence of corrosion products accelerates corrosion, because the corrosion product is cathodic with respect to the uncorroded metal. From this, the inference has been drawn that a pit once formed tends to deepen at an increased rate because of galvanic action. The theory that the limitation of oxygen at one portion of a surface tends to make that portion anodic also suggests accelerated corrosion at the bottom of pits. The data in Tables 5, 6, and 7 do not substantiate this conclusion but rather tend to show that deepcorrosion product retards corrosion and that, in the later stages, increased corrosion is in the form of spreading more than deepening of the corroded areas, although the latter process continues at a decreasing rate. If later data bear out this conclusion, it will be evident that in determining the future life of a pipe line from the depth of corrosion at the time of inspection it will be incorrect to assume, as is now frequently done, that the depreciation is proportional to the age of the line.

\section{COMPARISON OF SOILS}

(a) With Respect to Rates of Corrosion.-Several investigators are attempting to develop methods for determining the corrosiveness of soils by short-time tests. For the trying out of these methods, data on soil corrosiveness as determined from field 
conditions are helpful, and the Bureau of Standards data have been used frequently for this purpose. Since rates of corrosion as given for each of the three periods were based on a comparatively few specimens and as the rates for ends of the different periods in some cases varied widely, it sometimes has been difficult to decide the rate of corrosiveness that should be assigned to a soil. It would seem that the most reliable value now obtainable would be based on the total number of specimens involved, on the time of their exposure, and the surface exposed. Table 7 has been prepared on this basis. The values for rates of corrosion were obtained by dividing the sum of all the losses of all the wrought specimens so far removed from a soil by the product of the total area of the specimens removed at one time multiplied by the sum of the periods of burial; that is, approximately 12 years. The result thus obtained was an average rate of corrosion weighted with respect to the size of the specimens and the time they were exposed.

TABLE 8.-Relative corrosiveness of soils

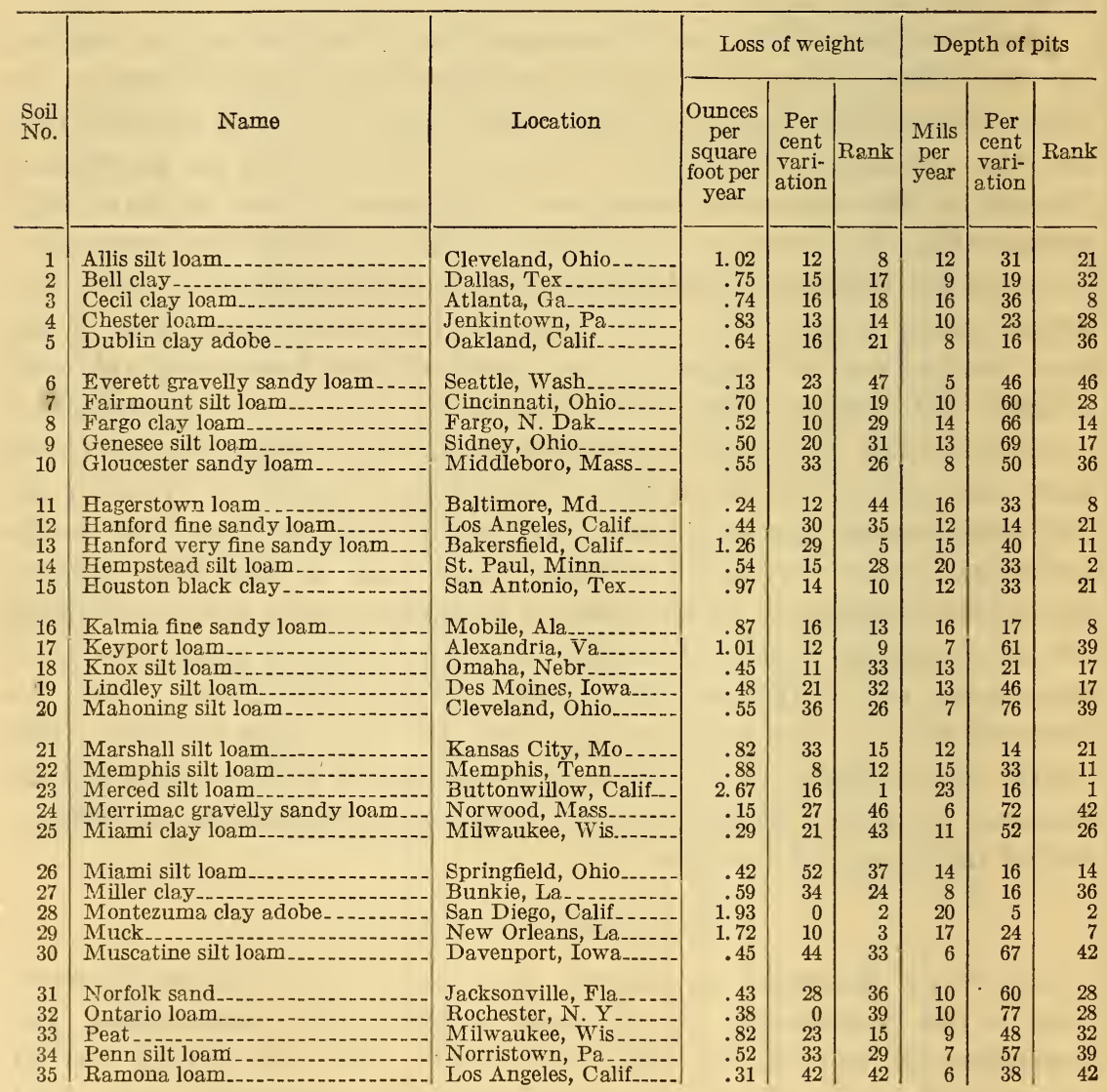


TABLE 8.-Relative corrosiveness of soils-Continued

\begin{tabular}{|c|c|c|c|c|c|c|c|c|}
\hline \multirow[b]{2}{*}{$\begin{array}{l}\text { Soil } \\
\text { No. }\end{array}$} & \multirow[b]{2}{*}{ Name } & \multirow[b]{2}{*}{ Location } & \multicolumn{3}{|c|}{ Loss of weight } & \multicolumn{3}{|c|}{ Depth of pits } \\
\hline & & & $\begin{array}{l}\text { Ounces } \\
\text { per } \\
\text { square } \\
\text { foot per } \\
\text { year }\end{array}$ & $\begin{array}{c}\text { Per } \\
\text { cent } \\
\text { vari- } \\
\text { ation }\end{array}$ & Rank & $\begin{array}{l}\text { Mils } \\
\text { per } \\
\text { year }\end{array}$ & $\begin{array}{l}\text { Per } \\
\text { cent } \\
\text { vari- } \\
\text { ation }\end{array}$ & Rank \\
\hline 36 & Ruston sandy loam. & Meridian, Miss. & 0.36 & 31 & 40 & 11 & 36 & 26 \\
\hline 37 & St. Johns fine sand. & Jacksonville, Fla & .91 . & 25 & 11 & 14 & 45 & 14 \\
\hline 38 & Sassafras gravelly sandy loam. & Camden, N. J & .16 & 6 & 45 & 6 & 55 & 42 \\
\hline 39 & Sassafras silt loam & Wilmington, Del & .63 & 27 & 23 & 9 & 30 & 32 \\
\hline 40 & Sharkey clay... & New Orleans, La. & 1.03 & 9 & 7 & 13 & 21 & 17 \\
\hline 41 & Summit silt loam. & Kansas City, Mo_ & .64 & 17 & 21 & 12 & 47 & 21 \\
\hline 42 & Susquehanna clay.. & Meridian, Miss _ & 1.19 & 9 & 6 & 19 & 28 & 4 \\
\hline 43 & Tidal marsh......... & Elizabeth, N. J & 1.31 & 11 & 4 & 18 & 32 & 6 \\
\hline 44 & Wabash silt loam & Omaha, Nebr. & .39 & 5 & 38 & 15 & 47 & 11 \\
\hline 45 & Unidentified alkali soil-. & Casper, Wyo_- & .70 & 33 & 19 & 9 & 44 & 32 \\
\hline 46 & Unidentified sandy loam. & Denver, Colo.... & .58 & 22 & 25 & 19 & 46 & 4 \\
\hline 47 & Unidentified silt loam.. & Salt Lake City, Utah. & .32 & 16 & 41 & 5 & 74 & 46 \\
\hline
\end{tabular}

Table 5 shows that in most soils the rate of loss of weight varied from year to year. Probably a small part of this variation was accounted for by differences in the surface conditions or composition of the specimens. In many of the soils a more important cause of the differences was the nonhomogeneity of the soil, which in a 100-foot trench may vary appreciably in texture and moisture. A third possible cause of variations in rates was the variation in rainfall and temperature from year to year. To these possible causes of irregularities in the data must be added the accelerating or inhibiting effects of the corrosion products. All of these things tended to make the data for any one period differ somewhat from those of some other period and must be considered in selecting figures for the relative or absolute corrosiveness of soils. In order to indicate roughly the magnitude of these variations, the departure of the average rate of loss of weight from the weighted average has been indicated in column 5 of Table 8. The value of the average variation was obtained by subtracting from the weighted averaged rate of loss, as given in column 4, the average rate of corrosion of the wrought specimens for each period. The sum of these differences (three in any one soil) was then divided by three times the average weighted rate of loss and multiplied by 100 .

The figure thus obtained was not a measure of the accuracy of the data, since part of the deviation was caused by changes in the corrosion phenomena. It is rather an indication of the extent to which the weighted rate of loss obtained at this time is indicative of the final results. In general, the indications are that more data are necessary for rates of loss that are accurately representative of soil corrosivity.

(b) With Respect to Rates of Pitting.-Although for a study of corrosion from a chemical standpoint data on rates of loss of weight are probably more significant, many are inclined to judge the seriousness of corrosion by the depth of the pits. For the benefit of 
those who wish to study corrosion from this standpoint columns 7, 8, and 9 of Table 8 have been prepared. Column 7 is based on the measurement of the deepest pits on the wrought specimens removed in 1924, 1926, and 1928. Usually two specimens of each material were removed from each soil at the close of each period. This gave a total for each period of eight $11 / 2$ inch and eight 3 inch specimens. As there is a probability that a deeper pit will occur on a 3 -inch specimen than on a $1 \frac{1}{2}$-inch specimen of the same material because of the greater area of the former, it was decided to treat two $11 / 2$-inch specimens as equivalent to one 3 -inch specimen in weighting the data. The values given for the rates of pitting were, therefore, weighted in accordance with the area of the specimen and the duration of exposure. The following method of determining the weighted average rate of pitting for the wrought materials was used. For the $11 / 2$-inch specimens the maximum pit for each material was taken for each period (12 pits); for the 3-inch specimens the maximum pit for each period on each specimen was selected (24 pits). The sum of all these pits (36 pits) was then divided by the number of specimens, usually 36 , and by the average time the specimens were buried.

To get the deviation from the mean, the average rate of pitting of the wrought materials for each period was subtracted (algebraically) from the weighted mean average for the three periods. The average difference for the three periods was then obtained. This average difference was then divided by one hundred times the weighted average to get the percentage variation.

Since in most soils there was a tendency for the rate of penetration to decrease with time,the percentage deviation as expressed in Table 8 is not an indication of the precision of the pitting data, but an indication of the tendency of the rate of pitting to change. This tendency to change has, of course, an important bearing on the value of the weighted average rate, as now computed, as an indication of the final rate of pitting, and where the percentage deviation is large we must conclude that the ultimate rate of pitting is correspondingly uncertain. Since the specimens which have been in the ground the longest most nearly represent the condition of old pipe lines, it might be better to use the data in Table 6 rather than that in Table 8 for determining the relative pitting.

(c) With Respect to Soll Texture.-The texture of the soil influences the access of oxygen and moisture to buried materials, and in an analysis of the causes of variations in the corrosiveness of soils soil textures should be considered. In doing so the student should bear in mind the fact that the system of soil nomenclature which has been used to designate soils was developed for use in connection with agricultural problems in which the surface layers play the most important part. On this account the texture of the 
soil as indicated in the soil name is that of the first 18 inches of soil and may or may not be that of the subsoil in direct contact with the pipe specimens in the Bureau of Standards tests. Those wishing information as to the texture of the soil adjacent to the pipe should consult the soil descriptions given in Technologic Paper No. 368 of the Bureau of Standards. An idea of the soil texture adjacent to the pipe can also be obtained from Table 3, since there is a fairly close relation between soil texture and the amount of colloids. ${ }^{5}$

\section{COMPARISON OF MATERIALS}

Of primary importance to many readers of the reports on soil corrosion is the question of the relative merits of the materials under test. We wish to point out that the object of the investigation is to study the relation of soils to corrosion of pipe lines rather than to determine the relative merits of different kinds of pipes and that the data required for the latter purpose must necessarily be much more extensive than for the former. At the end of each test period 24 samples of pipe were removed from each location, but of these only two were of one material and manufacture. Frequently the data on the two specimens of the same material differed as widely as those for different materials. This may be accounted for by the unavoidable differences in individual specimens of almost any commercial pipe material or by minor differences in the composition, texture, or moisture of the soil in different parts of the same trench. It is expected that as the experiment runs for longer periods and more specimens of each material are removed for examination these accidental differences will counteract each other and the average results will become fairly representative of the characteristics of the several materials tested. At this time but half of the number of the bare pipe specimens have been removed. By weighting the data in accordance with the time each set of specimens was exposed before removal, we find that the weight to be assigned to the data obtained to date is to that at the end of the test as 12 is to 42 . Evidently, therefore, the dependability of the final results will be much greater than any that are now available. The reliability of individual figures improves as the specimens are exposed longer because the percentage error in weighing and measuring becomes less. Trench conditions are becoming more stable and more representative of the conditions to which pipes are exposed. There appear to be progressive changes in the rates of corrosion and pitting, and these changes in rates seem to differ for different materials. On account of all of these things which may affect the final results of the test, the Bureau of Standards believes that it is unwise at this time to draw conclusions as to the relative merits of the materials under test, and the data are published

${ }^{5}$ See Methods of Classifying Soils, B. S. Tech. Paper No. 368, p. 459. 
from time to time prior to the conclusion of the investigation only in order that those cooperating with the bureau in the study of corrosion may have promptly all the data they have helped to obtain. It is earnestly hoped that all those who study these data will draw a sharp distinction between the actual facts presented and conjectures reached through attempts to interpret the relation between the now limited data and some specific corrosion problem.

\section{APPLICATION OF RESULTS TO SPECIFIC CORROSION PROBLEMS}

A number of requests have been received for data on the corrosiveness of the soil in certain cities and the best material for use there.

Such requests show progress in that they indicate the recognition that different soils may call for different pipe materials, but unfortunately the area within a city usually includes a number of widely different soils, and the selection of the best pipe not only requires more data on pipe materials than are now available but a soil survey of the route of the pipe line and a correlation of the soil data with corrosion. The data for such a correlation are also inadequate at this time, although the problem is being studied at the Bureau of Standards and by a number of other organizations. It appears probable that a method for roughly estimating the corrosiveness of a soil in any locality will be available within a few years.

\section{RESULTS OF SUPPLEMENTARY RESEARCH ON PIPE LINES}

The early results of the soil-corrosion investigation made it apparent that the work already under way would not solve some of the most pressing corrosion problems and that additional tests would be required to explain the causes of corrosion, identify corrosive soils, and suggest means of mitigating corrosion. Some of this work has been undertaken during the past year. The results are insufficient to be conclusive but are worthy of note because of the things which they suggest.

\section{INSPECTION OF GAS MAINS}

However planned, laboratory or field experiments seldom, if ever, completely duplicate actual operating conditions. For this reason the cooperation of a number of gas companies in the study of the condition of their cast-iron pipe lines was secured. The purpose of the undertaking was to determine the extent of corrosion on lines passing through a few of the soils in which the bureau's specimens were buried and to make a comparison between the corrosion of these lines and that of the specimens.

Attempts to find suitable places for this comparison made it evident that a large portion of the gas mains in city streets pass 
through earth which has been so modified by city conditions, such as grading, filling, and artificial drainage, that it does not fit into the recognized soil classification, and the data on such soils are not entirely suitable for comparison with those on the selected soils in which the field specimens were buried. Pipes were examined in 40 locations representing Cecil, Memphis, Muck, Norfolk and Susquehanna soils. In Cecil and Norfolk soils the conditions of the pipes checked quite well with the experimental data. In Muck, where there was a possibility, though little probability, of electrolysis, the pipes were more seriously corroded than was expected, while in Memphis silt loam the pipes, most of which were much older than the test specimens, showed a lower rate of pitting than was anticipated. Susquehanna soils gave inconsistent data, probably because this soil group represents soils in the process of change, and, therefore, soils which differ chemically although classified as the same soil. In the case of the other soils studied the same soil in different localities gave fairly consistent indications as to corrosive properties. On the whole, the results of the examinations were somewhat unsatisfactory as checks on the experimental data. In one respect, however, the data were consistent. In each soil, comparison of the depth of pits on pipes of different ages showed that the rate at which pits penetrate the pipe decreases with time. This is in accord with the experimental data and indicates that a straight line depreciation curve should not be used for the determination of the life of an underground pipe system.

\section{CORROSION ACCOMPANIED BY GALVAIIIC ACTION}

In the summer of 1927 the Bureau of Standards cooperated with a midcontinent oil company in an attempt to determine the relation between observed corrosion on a line which was being removed and soil conditions. It was observed that where the line passed through certain geological strata corrosion was severe while it was a minimum in one other stratum. Measurements of differences of potential along single pipe lengths indicated electrical currents which were different at different points on the pipe, but which were steady and changed little from day to day. Figure 1 shows the currents in one section of the line. The direction of flow of the current on the pipe was different at different points, although at a given point the current was steady. Considerably more corrosion was observed on lengths of pipe which were discharging current than on lengths collecting current. The conclusion was reached that the passage of the pipe line through different soils resulted in the formation of a galvanic cell, the electrodes of which were in some cases a mile or more apart.

In the case referred to, the maximum current on a 4-inch steel line was slightly more than 1 ampere. A similar study was later made on an 8-inch steel line in California in which a similar relation between 
corrosion and current discharge was observed and a maximum current of 4.6 amperes found. If, as seems probable, these galvanic cur-

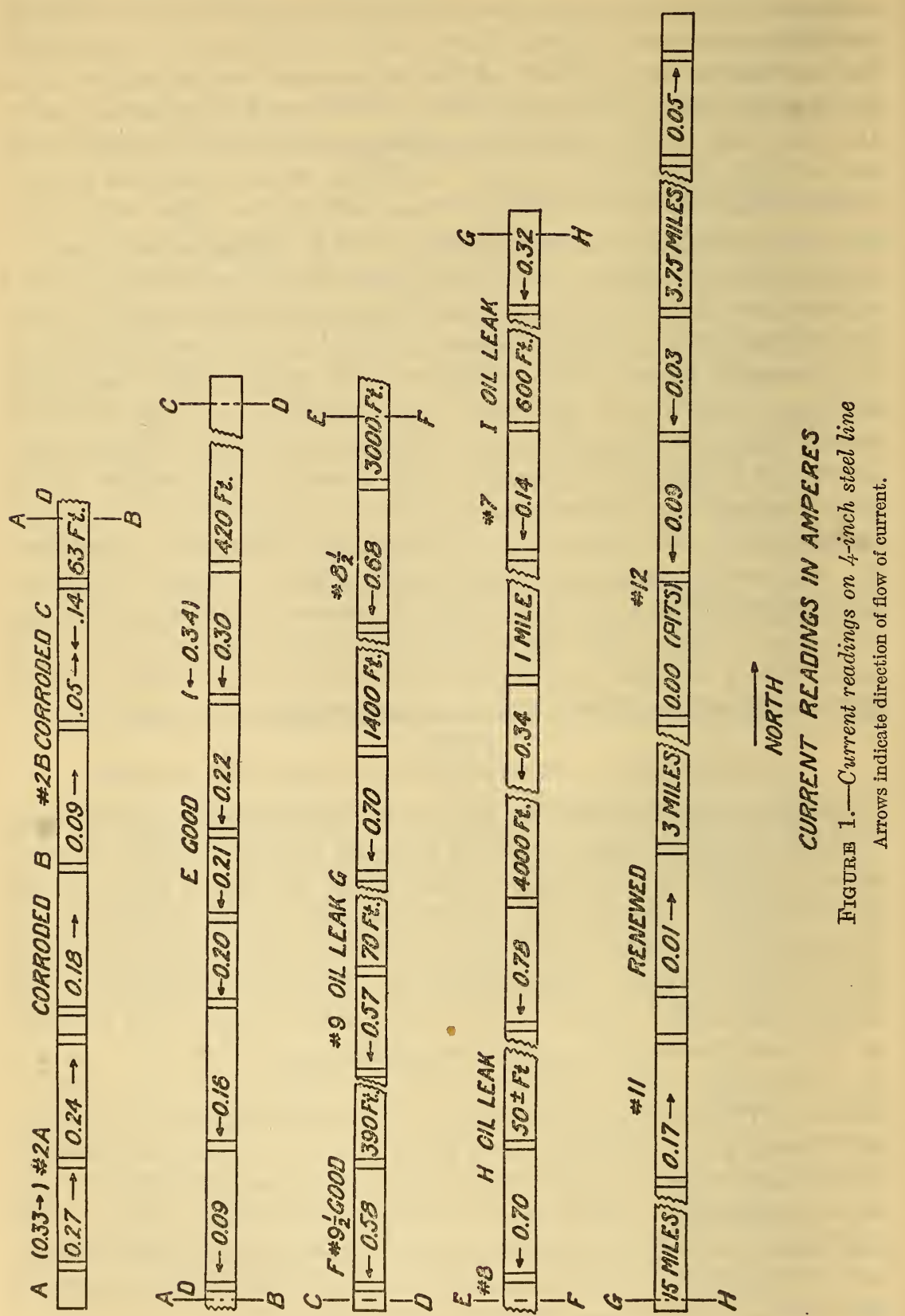

rents accompany pipe-line corrosion, it would indicate that corrosion on short isolated sections of pipe should be different from that on a continuous line of the same material under similar soil conditions and 
that a welded or screw-jointed line will corrode more rapidly in some locations than one with numerous insulating joints. It would indicate also that a protective coating should be an electrical insulator and that coating the pipe at points of no corrosion assists in reducing the corroding action at other sections. The question has a bearing on the proper specifications for protective coatings and on the method of their application.

TABLE 9.-Corrosion of high-silicon cast iron and lead sheath

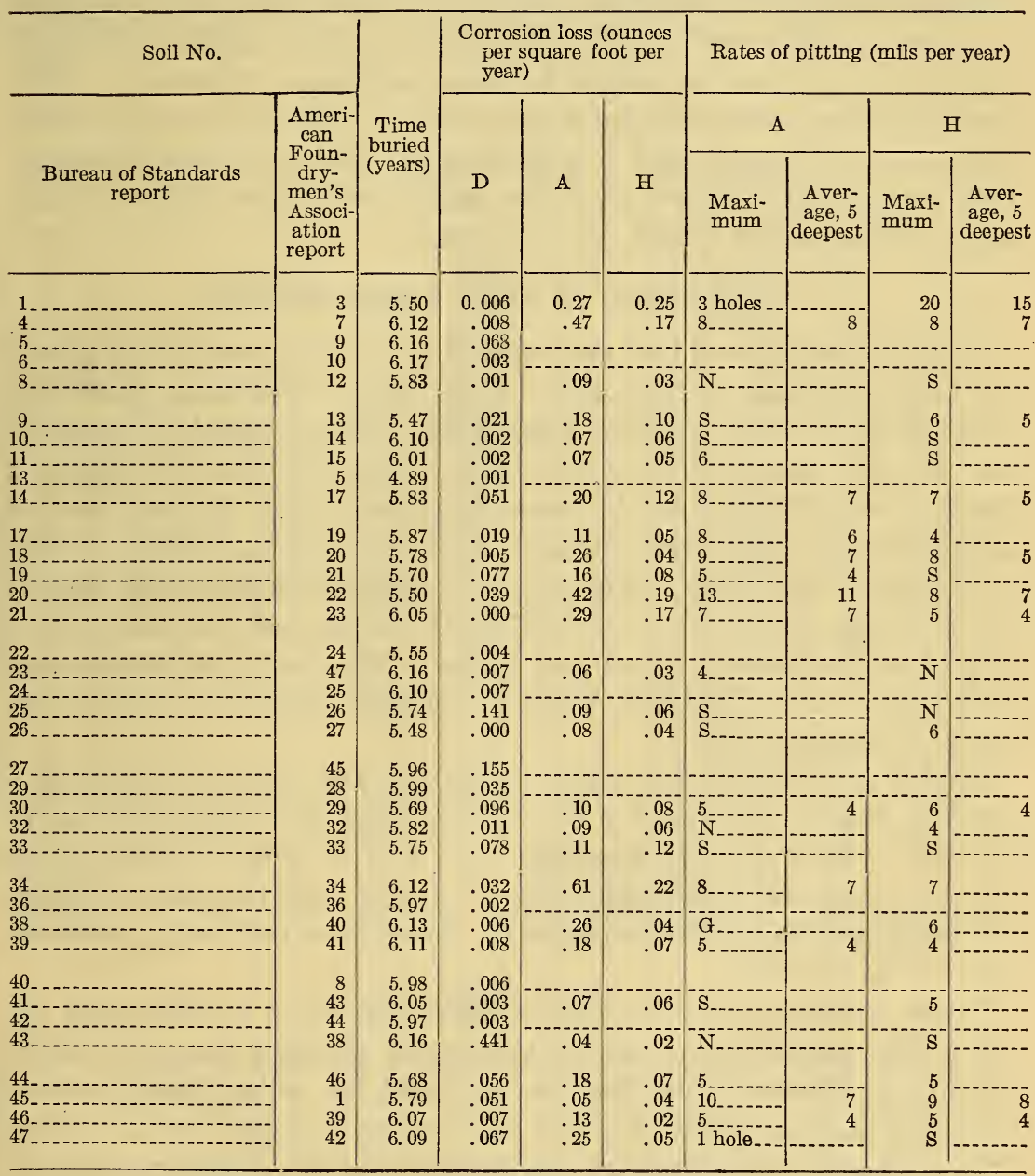

A, Antimony lead.

D, high silicon cast iron.

$\mathrm{H}$, commercially pure iron.

$\mathrm{N}$, no pitting.

$\mathrm{S}$, few pits less than 0.020 inch.

$G$, general pitting less than 0.020 inch.

Dimensions of exposed areas of specimens:

A, 20.5 by 8.5 inches by 0.130 inch.

H, 20.5 by 3.5 inches by 0.112 inch.
D, ID, 3 inches. OD, 3.625 inches. Length, 6 inches. Area, 131.52 square inches. 


\section{RESULTS OF TESTS OF OTHER MATERIALS USED UNDER GROUND}

\section{CORROSION OF HIGH-SILICON CAST IRON}

There were included in the materials removed in 1928 specimens of cast iron containing approximately 14 per cent of silicon. While these specimens were in the form of short sections of pipe, and while the material is used for plumbing in chemical plants, its physical properties are so different from those of the other pipe materials under test that it seems best to report on it separately. Table 9 gives the average rate of loss of weight for the specimens removed in 1928. Two specimens were removed from each soil. No pits of appreciable depths were observed, and it will be noted that the losses in weight were very small. In many of the soils most of the surface of the specimens appeared bright after six years.

\section{CORROSION OF LEAD CABLE SHEATH}

In 1922 specimens of lead cable sheath, such as is used for telephone and power cables, were buried in 27 soils; additional specimens were buried in other soils two years later. Before burial the sheaths were slit and opened out to form sheets. The specimens of telephone sheath were 0.13 inch in thickness and had a total exposed area of approximately 174 square inches. This material contained a small percentage of antimony. The other specimens of lead sheath were of commercially pure lead 0.112 inch in thickness and had an exposed area of approximately 72 square inches. The large specimens were designated "A" in Table 9, while the smaller specimens were designated by the letter "H."

Lead is so soft that it is easily scratched, and on this account it is probable that a small part of the loss recorded in Table 9 was due to handling rather than to corrosion. It will be noted that in most soils the corrosion losses and rates of pitting were somewhat greater for the sheath containing antimony. Specimens removed previously gave similar results.

These specimens were buried on edge directly in contact with the soil. The conditions to which they were exposed were, therefore, somewhat different from those encountered by cable sheaths in duct lines. Although cables in ducts are frequently partially in contact with mud and water, they are also exposed to air. It is impossible to say which condition is worse.

Occasionally lead-sheathed cables are buried directly in the earth. The data in Table 9 indicate that this is a questionable practice; since we found the antimony lead sheath punctured within six years in two soils and pits at least one-third of the thickness of the sheath in nine other soils at the end of the 6-year period. 


\section{CORROSION OF PARKWAY CABLE}

For burial directly in the earth a special cable has been designed. This consists of one or more rubber-covered copper conductors incased in lead sheath which is protected by a layer of jute impregnated with oil or bitumen followed by two layers of galvanized-steel tape wound spirally in opposite directions and an outer covering of bitumen-impregnated jute. Samples of this material were buried along with the samples of cable sheath. Table 10 indicates in a general way the condition of the specimens removed in 1928.

TABLE 10.-Condition of parkway cable

\begin{tabular}{|c|c|c|c|c|c|c|}
\hline Soil No. & $\begin{array}{c}\text { Time } \\
\text { buried } \\
\text { (years) }\end{array}$ & $\begin{array}{l}\text { Outer } \\
\text { fabric }\end{array}$ & $\begin{array}{l}\text { Inner } \\
\text { fabric }\end{array}$ & $\begin{array}{l}\text { Outer } \\
\text { Steel } \\
\text { tape }\end{array}$ & $\begin{array}{l}\text { Inner } \\
\text { steel } \\
\text { tape }\end{array}$ & $\begin{array}{l}\text { Lead } \\
\text { sheath }\end{array}$ \\
\hline $\begin{array}{r}1 \\
4 \\
8 \\
9 \\
9\end{array}$ & $\begin{array}{l}5.50 \\
6.12 \\
5.83 \\
5.47 \\
6.10\end{array}$ & $\begin{array}{l}\mathrm{G} \\
\mathrm{B} \\
\mathrm{F} \\
\mathrm{F} \\
\mathrm{B}\end{array}$ & $\begin{array}{l}\mathrm{G} \\
\mathrm{G} \\
\mathrm{G} \\
\mathrm{G} \\
\mathrm{G}\end{array}$ & $\begin{array}{c}\mathrm{R} \\
\mathrm{SR} \\
\mathrm{G} \\
\mathrm{SR} \\
\mathrm{G}\end{array}$ & $\begin{array}{c}\text { SR } \\
\text { SR } \\
G \\
\text { VSR } \\
G\end{array}$ & $\begin{array}{l}\mathrm{W} \\
\mathrm{TW} \\
\mathrm{TW} \\
\mathrm{TW} \\
\mathrm{TW}\end{array}$ \\
\hline $\begin{array}{l}11 \\
13 \\
13 \\
13 \\
13\end{array}$ & $\begin{array}{l}\text { 6. } 01 \\
5.89 \\
5.89 \\
5.89 \\
5.87\end{array}$ & $\begin{array}{l}\mathrm{B} \\
\mathrm{B} \\
\mathrm{F} \\
\mathrm{F} \\
\mathrm{G}\end{array}$ & $\begin{array}{l}\mathrm{G} \\
\mathrm{G} \\
\mathrm{G} \\
\mathrm{G} \\
\mathrm{G}\end{array}$ & $\begin{array}{c}\mathrm{G} \\
\mathrm{BR} \\
\mathrm{G} \\
\mathrm{G} \\
\mathrm{G}\end{array}$ & $\begin{array}{l}\text { G } \\
\text { SR } \\
\text { SR } \\
\text { SR } \\
\text { G }\end{array}$ & $\begin{array}{l}\mathrm{G} \\
\mathrm{W} \\
\mathrm{W} \\
\mathrm{TW} \\
\mathrm{G}\end{array}$ \\
\hline $\begin{array}{l}18 \ldots \ldots \\
19 \\
20 \\
21 \\
23\end{array}$ & $\begin{array}{l}5.78 \\
5.70 \\
5.50 \\
6.05 \\
6.16\end{array}$ & $\begin{array}{l}\mathrm{B} \\
\mathrm{F} \\
\mathrm{B} \\
\mathrm{F} \\
\mathrm{B}\end{array}$ & $\begin{array}{l}\mathrm{G} \\
\mathrm{G} \\
\mathrm{G} \\
\mathrm{G} \\
\mathrm{F}\end{array}$ & $\begin{array}{l}\text { SR } \\
\text { VSR } \\
\text { VSR } \\
\text { VSR } \\
\text { Failed }\end{array}$ & $\begin{array}{c}\mathrm{G} \\
\mathrm{G} \\
\mathrm{G} \\
\mathrm{G} \\
\mathrm{BR}\end{array}$ & $\begin{array}{l}\mathrm{W} \\
\mathrm{TW} \\
\mathrm{TW} \\
\mathrm{W} \\
\mathrm{W}\end{array}$ \\
\hline $\begin{array}{l}26 \\
30 \\
32 \\
34 \\
38\end{array}$ & $\begin{array}{l}5.48 \\
5.69 \\
5.82 \\
6.12 \\
6.13\end{array}$ & $\begin{array}{l}\mathrm{B} \\
\mathrm{F} \\
\mathrm{B} \\
\mathrm{B} \\
\mathrm{B}\end{array}$ & $\begin{array}{l}\mathrm{G} \\
\mathrm{G} \\
\mathrm{G} \\
\mathrm{G} \\
\mathrm{G}\end{array}$ & $\begin{array}{c}\mathrm{G} \\
\stackrel{R}{R} \\
\stackrel{\mathrm{G}}{\mathrm{V}} \\
\mathrm{VSR}\end{array}$ & $\begin{array}{c}G \\
\text { SR } \\
\text { SR } \\
G \\
G\end{array}$ & $\begin{array}{l}\text { TW } \\
W \\
W \\
\text { TW } \\
\text { TW }\end{array}$ \\
\hline $\begin{array}{l}41 \\
43 \\
45 \\
46 \\
47\end{array}$ & $\begin{array}{l}\text { 6. } 05 \\
6.16 \\
5.79 \\
6.07 \\
6.09\end{array}$ & $\begin{array}{l}\mathrm{B} \\
\mathrm{F} \\
\mathrm{F} \\
\mathrm{B} \\
\mathrm{B}\end{array}$ & $\begin{array}{l}\mathrm{G} \\
\mathrm{G} \\
\mathrm{G} \\
\mathrm{G} \\
\mathrm{G}\end{array}$ & $\begin{array}{c}\mathrm{SR} \\
\mathrm{R} \\
\mathrm{VSR} \\
\mathrm{BR} \\
\mathrm{G}\end{array}$ & $\begin{array}{c}G \\
\text { VSR } \\
\text { G } \\
\text { SR } \\
\text { G }\end{array}$ & $\begin{array}{c}\mathrm{W} \\
\mathrm{G} \\
\mathrm{G} \\
\mathrm{TW} \\
\mathrm{W}\end{array}$ \\
\hline
\end{tabular}

Rating symbols:

$B$, bad.

G, good.

$\mathrm{F}$, fair.

$\mathrm{R}$, rusted.
SR, slightly rusted.

VSR, very slightly rusted.

$\mathrm{BR}$, badly rusted.

TW, thin white corrosion product on lead sheath. W, white corrosions product on lead sheath.

\section{SUMMARY}

The specimens removed in 1924, 1926, and 1928, constitute half of the specimens buried in 1922, but on account of the longer time involved in the data on specimens to be removed later, the relative weight to be given data now available is less than a third that which should be assigned to the results at the end of the investigation. Through the cooperation of private organizations additional information on the properties of soils and materials are now available.

Supplementary field investigations have corroborated the bureau's results in their indication that the rates of penetration of pits in cast iron decrease with the age of the pipe. Limited studies of oil lines 
have indicated that part of the corrosion found is the result of the formation of a galvanic cell when the pipe line passes through two different soils. This has a bearing on the type of joint and the kind of coating to be used in such lines.

Considerable progress has been made in the laboratory study of corrosion.

Tables have been prepared showing the corrosion data for the specimens removed in 1924, 1926, and 1928. Data for the last two periods are, in most cases, similar and indicate that the conditions of test have reached a nearly steady state. There are no data indicating that the tentative conclusions drawn in earlier reports should be changed.

On the average the rate of corrosion was decreasing, although this was not universally true. The rate of pitting decreased in most soils, and increased corrosion seems to be largely the result of the spreading of the corrosion, penetration progressing more slowly than loss of weight.

Slight differences in the composition of different specimens of the same material, occasional flaws, and especially the variations in the soil at different points in the same trench result in variations in data which make it impossible to estimate the significance of small differences in apparent rates of corrosion until more specimens have been examined. It is therefore urged that no conclusions as to the relative merits of the materials or as to the ultimate life of any material be drawn until more data are available.

Washington, March 18, 1929 